\title{
Digitizing the field of women's Islamic education
} Changing infrastructures during coronavirus lockdown in Denmark

$\mathrm{T}$ his article builds on fieldwork conducted in 2019 and 2020 and examines the implications of Covid-19 lockdown for the engagement of Danish Muslim women in Islamic educational activities. Drawing on Deleuze and Guattari (2012) and Larkin (2008b), it displays how technological infrastructure influences religious practice and the constitution of religious space. For the women engaged in Islamic education, the forced use of digital-media technologies unmoored conditions for being at activities, reorganized time and space, and changed conditions for relating to communities. As home became the territory from where the women conducted all religious practices, including educational activities, classes and seminars were accessed on more individualized terms and became more easily integrated with other everyday activities. This made room for expanding engagement and accessing more diverse educational opportunities. At the same time, it withdrew the women from spaces of bodily and sensory togetherness, where feelings of community and connection would usually be nurtured.

IT IS AN EVENING IN EARLY MARCH 2020. I have come to a mosque to join a class for female converts to Islam to gain more knowledge about Danish Muslim women's educational activities for my doctoral research. It has been a little while since I last visited the class, and when the teacher Samira arrives, we greet each other with a hug. ${ }^{1}$ After some introductions, Samira starts her lecture, which is today a rather informal talk about du'as based on reflections caused by the new coronavirus that has spread elsewhere in the world and is now also emerging in Denmark. ${ }^{2}$ As a medical doctor, Samira also uses the lecture to comment on health matters in relation to the spread of the virus and instructs us to be cautious.

On the next evening, 11 March, however, I do not worry about visiting another interlocutor in her private home. This young woman, Mariam, has kept a logbook on her Islamic educational activities for a week, and we have agreed that I will pick

1 Samira's name as well as all other names are pseudonymized to secure participants' confidentiality.

$2 D u^{\prime} \vec{a}$ is a prayer of individual or collective invocation addressed to God on behalf of oneself or someone else, or against something (Gardet 2012). The du'a' prayers are distinct from the șalāh prayers performed at specific hours five times daily, and can be performed at any time. Note that in order to lighten the reading I have in this article chosen to simplify transliteration and leave out markers of emphatic consonants as well as long vowels, but keep 'ayn. In footnotes, full transliterations are, however, provided for terminological clarity. 
up her handwritten notes this evening. As I am on my way out of the kitchen, Mariam's sister shouts from upstairs that the Danish prime minister is 'closing down Denmark', and that they cannot go to school the next day (field notes, March 2020). A little stunned, Mariam and I exchange a couple of sentences on the matter before we say goodbye with a short hug. I rush to my car and turn on the radio to hear more.

The events that these short stories from my fieldwork portray came to be significant for the collection of material for my Ph.D. research as they represent the moments where the world for me and my interlocutors turned upside down. ${ }^{3}$ For some time after these events, my study was situated in a context marked by Covid-19 lockdown and restrictions. This saturated daily life with digital infrastructure in new and intensified ways (Markham 2016, 2020), and this gave rise to transformational processes within religious communities, which tried to continue their activities on various online platforms (Larsen et al. 2021: 78).

My point of departure here is that media technologies and practices of mediation play a constitutive role 'in giving shape to diverse forms of religiosity' (Hirschkind and Larkin 2008: 3 ) and potentially reconstruct time, space and norms of practice. Based on this assumption, this article investigates the implications of coronavirus lockdown and restrictions for the engagement of Danish Muslim women in Islamic education. Drawing on Gilles Deleuze and Félix Guattari (2012) and Brian Larkin (2008b) it examines especially the ways in

3 Evidently, people all over the world were and are affected by the pandemic. Since this article addresses the relations between my fieldwork in Denmark and the coronavirus crisis, I take into account solely the Danish context. which technological infrastructure forms religious territories, and asks what kinds of relations and modes of engagement specific technological infrastructure promotes and enables (see Stjernholm 2020).

Throughout the article, I will refer to 'the lockdown'. By this term, I mean to capture the situation in Denmark that began on 11 March 2020, when the first extensive restrictions to curb the spread of Covid-19 were launched. While a law shutting down religious buildings was only brought into force on 4 April 2020 (Kühle 2021: 20), Danish authorities did, nonetheless, urge all religious communities to close their buildings immediately after 11 March (Kühle 2021: 20). To my knowledge, this recommendation was followed by the mosques and other Islamic institutions included in my research. Tina Larsen and her co-authors (2021: 90) have also found that most Danish Muslim communities reacted according to governmental restrictions and recommendations and have even promoted these. While these comprehensive restrictions that shut down for example schools and religious buildings were lifted during the late spring and early summer of 2020 , religious institutions were 'still subject to detailed restrictions on the number of people who could be present on public premises' after that (Kühle 2021: 20). Continuing in both 2020 and the first half of 2021 , both national and local restrictions were implemented and lifted on and off. When I refer to the lockdown, I refer somewhat loosely to this situation of restricted social gathering that was initiated in March 2020 but, to differing degrees, lingered on for over a year. 


\section{Theoretical framework}

Mediation has always been present in religion (Meyer 2020) as well as in the Islamic history of preaching and teaching (Stjernholm and Özdalga 2020: 10). A line of research within the study of Islam has investigated the use of media and communication technologies in religious practices, especially those including preaching and knowledge dissemination. Charles Hirschkind (2006, see also 2008) has, for example, examined practices of listening to cassette sermons in contemporary Egypt. Hirschkind shows that specific historical and political developments make a specific ethical, agentive listener prominent, and that this is promoted through and relies on specific media technologies. Other authors have likewise pointed to relations between religious transformations and the use of media technologies (e.g. Larkin 2008a; Meyer 2011; Schulz 2012a, 2012b; Moll 2018, 2020). Within this line of research, the specific materiality of distinct mediation is scrutinized, and use of voice, pictures, sound etc. proves to be important for the work of media technologies in shaping religious forms and their ideological and theological underpinnings (e.g. Hirschkind and Larkin 2008; Sterne 2008; Schulz 2015; Stjernholm 2020). Religious practice and knowledge dissemination relying specifically on digital modes of communication have also been inquired into (e.g. Hirschkind 2012; Waltorp 2015; Aarset 2016; Stjernholm 2019, 2020; Makboul 2020). These studies show that digital media provide specific possibilities for preachers and specific modes of engaging and relating caused by the spatial and temporal economy that digital media establish (Stjernholm 2020: 147). Recent research has also begun to describe the implications of digitization arising from the coronavirus lockdown for Muslim communities (e.g. Gori 2021; Kühle and Larsen 2021; Sorgenfrei 2021).

This article adds to the literature with a local case study and takes its point of departure in experiences and practices of Muslim individuals, with a specific attention to aspects of spatiality. For this purpose I employ Deleuze and Guattari's (2012) conceptions of spacialization, that is the construction of space or territory. Using the terminology of Deleuze and Guattari, one could say that technologies are part of specific territories, which they also produce through their organization of, for example, sound and pictures (see also Bandak 2014). 4 Places do not 'pre-exist', Deleuze and Guattari suggest (2012: 362). They become constituted through sensory and material components: 'Radio and television sets are like sound walls around every household and mark territories' (p. 362). As we build infrastructure, they argue, we also build worlds and specific ways of inhabiting them (p. 449). In that way, infrastructure is territorializing; it cuts out spaces with specific functions, affecting also the way bodies move and work within these spaces (pp. 375-6).

In his book on the influence of media infrastructure on Nigerian urban life, Brian Larkin (2008b) analyses the connection of

4 A Thousand Plateaus (1987/80 is one of the principal works of Deleuze and Guattari. The book lays out a quite extensive ontology of becoming. Referring to A Thousand Plateaus in this article, I attend not as such to ontological questions, even if my approach is informed, for example, by the idea that places become. I refer mainly to the book's eleventh chapter on the constitution of territories through sonic rhythms. My application is pragmatic; it forefronts empirical material and takes concepts as tools to analyse this (Massumi 2012: xiii). 
infrastructure to the state and its citizens, and shows how changes in technological infrastructure work to reorganize notions and norms of space and time (see also Larkin 1998). Technological infrastructure such as radio and cinema produces specific subjects and specific consumers, and also changes relations between public and domestic space, Larkin shows (2008b: $48-52,70)$. Collapses, changes or continuations of such infrastructure affect the way it further shapes rhythms and practices of everyday life. For example, Larkin shows that the earliest introduction of the radio as something only broadcast in public spheres addressed its listeners as 'equivalent members of a public' (p. 52). The radio was in itself instituting this public through its contribution to the urban soundscape. With the introduction of transistors, sound became privatized, as radio was now 'controlled by individuals, with the sound kept low, usually for one person or groups of three or four' (p. 70). Relying on both Larkin and Deleuze and Guattari, I perceive 'Infrastructures [not just as] technical but also conceptual objects' (p. 244) embedded in and producing territories and subjects. They structure the possibilities of everyday life and establish specific modes of relating between institutions and subjects, among citizen subjects, and to other territories. These possibilities and relations rely importantly on technological constructions, and both Larkin (pp. 242-50) and Deleuze and Guattari (2012: 389) thus emphasize that meaning and materiality are interrelated and become established in connection with each other.

\section{Materials and methods}

The material dealt with here was collected for my Ph.D. research concerning the engagement of Danish Muslim women in
Islamic educational activities. ${ }^{5}$ The women appearing in the study all engage in Islamic educational activities as either students or teachers, or both. This means that they schedule time for intellectual engagement with Islam in their everyday life. The extent to which they do this varies, as do their modes of engagement, but common for them is that they see the quest for knowledge as an important aspect of being Muslim. The majority of the women seek Islamic knowledge within formalized activities such as classes or seminars, most commonly held in mosques, but they also do so on more individual terms and in private settings such as study groups. The study includes both women who were born into Muslim families and women who have converted to Islam.

The collection of material for this research began in April 2019 and concluded in July 2020. Additionally, I carried out follow-up conversations with five women in the early summer of 2021 . In these conversations, the theme of coronavirus lockdown and restriction was especially prevalent. The specific methods employed for data collection are field observations, interviews and logbooks kept by individual women.

Observations were conducted in various places where women's Islamic education takes place. I mainly observed classes and seminars on different Islamic subjects in mosques, but I also carried out observations in more private settings. Before the lockdown, I made only limited numbers of

5 My study is part of the research project 'Rearticulating Islam: A New Generation of Muslim Religious Leaders' at the Department of Cross-Cultural and Regional Studies at the University of Copenhagen, led by Assistant Professor Simon Stjernholm. It has been generously funded by VELUX FONDEN. 
observations of education in private online fora. After the lockdown, all observations I made were online. This also included publicly broadcast seminars on Facebook, but the vast majority of events were online classes on platforms with private rooms such as Zoom, that I was invited to participate in by teachers. Additionally, I participated in a WhatsApp group during my fieldwork, and the importance of this group to my research became more significant during the lockdown. In addition to observations, I conducted interviews with 23 women, most of whom I met at the educational activities they engage in as teachers or students. The interviews provided me with further information on the women's educational trajectories, and on their motivations for engaging intellectually with Islam. Lastly, I rely on logbooks which also provided further knowledge on the kind of educational activities that the women participate in. Four women twice kept logbooks on their engagement in Islamic education for one week. For this, they were instructed to put down all kinds of activities relating to searching out Islamic knowledge or dissemination of such knowledge. The logbooks were fruitful specifically for capturing the details that often got lost in interviews, and also uncovered further potential sites to conduct religious life, including educational activities (Ammerman 2013). These logbooks were kept both before and during the lockdown. During the lockdown, three additional women kept logbooks for a few days on their religious activities during Ramadan 2020. As we were all restricted from meeting for activities and events that would usually take place publicly or in more private social gatherings during Ramadan, the women had to cultivate a domestic Ramadan celebration. Since I could not take part in this, logbooks were a method for me to get some kind of insight into these activities.

The sudden change in my mode of accessing my field of interest, caused by the coronavirus lockdown, highlights the inherent instability of research fields (Amit

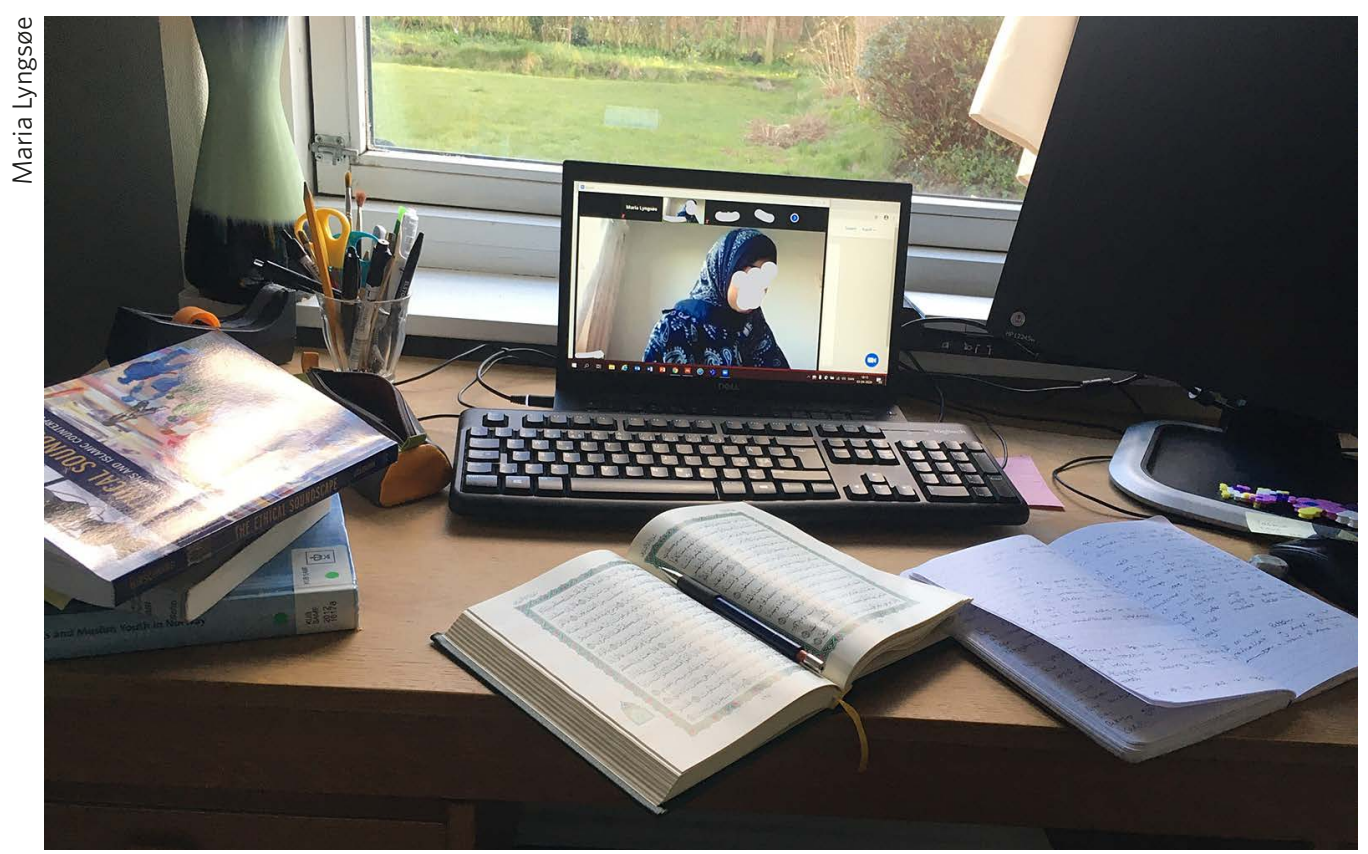

Participating in a Quran class from my home office. March 2020. 
2000: 12; Ahlin and Li 2019: 17-18). While my fieldwork up until 11 March 2020 had to a large extent been defined by spatially specific places I visited and the people I met in these places, the digitization meant that the importance of these places shifted. Tanja Ahlin and Fangfang Li (2019) propose that we define our fields of investigation not in terms of geography, as a specific place, but as 'field events' (p. 4). When doing fieldwork through digital means, it was exactly the events rather than the places that defined my field, as I accessed them all from my home environment. The WhatsApp group was likewise immediately available to me, and I could actually enter this specific corner of my field at any time and anywhere. In this way, digitization also 'reconfigur[ed] space and time' (Mittermaier 2011: 226) for me, as I could literally be at home or even rushing to buy groceries while accessing or connecting to my field of inquiry. This shift also introduced the women to my domestic space through the screen, showing my interior decorations, or through the microphone that would sometimes include sounds such as my children playing outside the door. In a similar manner, the digitization of methods also seemed to draw me closer to the homes and everyday lives of my interlocutors. I was no longer meeting people in public institutions but connected digitally with the women more directly in their everyday environments. Entering the digital life of the religious environments and people we study may precisely offer the potential to investigate this beyond public or institutional means, as Kayla Wheeler also argues (2017: 164; see also Cheruvallil-Contractor 2015). At the same time, however, I experienced how the digitization of my fieldwork also impeded the possibility of establishing the kind of familiarity and more intimate conversations that are usually perceived as a defining aspect of fieldwork (Harvey 2014). For example, small talk and informal connections were much more difficult to establish when physically separated.

As the data collected is sensitive, for example concerning the religious identification of specific persons, it has also been approved by the Faculty of Humanities Research Ethics Committee and registered with the Danish Data Protection Agency. ${ }^{6}$ Furthermore, the research adheres to rules set by the General Data Protection Regulations (GDPR); this especially concerns digital data. Specific ethical considerations also relate to digital fieldwork and the access to online forums. When accessing online platforms, it is easier to stay anonymous and invisible as a researcher (Cowan 2014: 468). Special attention must therefore be paid to ensuring visibility and clarity about one's intentions when doing research online (Wheeler 2017: 166). Informed consent should likewise be secured. In publicly broadcast seminars, for example on Facebook, I received consent from organizers to participate. In such settings, it was not possible to be visible, nor could I receive informed consent from participants. In order to follow principles of ethical conduct, I did not include participants in my research when carrying out such observations. Participating in Zoom meetings and WhatsApp groups, I made an effort to receive consent. In the Zoom meetings, I secured my visibility by always having my camera turned on, even if I was the only one to do so. Bodily presence in a physical meeting secures one's visibility; I intended my visual presence in online meetings to do the same. I also made sure to introduce myself and my purpose

6 In Danish, respectively Det Humanistiske Fakultets Forskningsetiske Komité and Datatilsynet. 
in participating. In the WhatsApp group, I presented myself and my intentions at the time I was added and wrote a thank-you post when I left. The fluidity of content in this group and the constant flow of posts meant that it was, however, not possible to ensure that everyone actually saw my posts. I relied therefore also on the acceptance of the leader of the group to carry out research. Acknowledging the risk of invisibility and the fact that the WhatsApp group was a forum for sharing very diverse and sometimes personal posts, I decided that the ethically correct way for me to handle content from the group was to not quote directly from posts but only refer to content by paraphrasing (Cheruvallil-Contractor 2015: 69). In this context as elsewhere, I have thus been guided by a wish to account in detail for events and the experiences of my interlocutors without exposing any individual.

\section{Changing Islamic educational territories}

The transformation of infrastructure during lockdown affected the mosque communities and the Muslim women included in my research, and the ways in which they engaged in and accessed Islamic educational activities. Many women used to go to mosques or Islamic institutes every week for classes or seminars; when lockdown restricted this usual way of cultivating their religious knowledge, it also affected thyeir religious territories, in that their own homes became the places from which religious engagements of every kind, including Islamic educational activities, were maintained. Comparing the logbooks of the women who kept them both before and during lockdown, it becomes very clear how home came to function as the territory for religious activities.

Adila was a woman in her fifties participating in a Quran class, that is a class on
Quranic recitation, where I also met her. ${ }^{7}$ For the first three months we knew each other, we only met online since I joined the Quran class just after lockdown was launched. I was only able to meet Adila and the other participants physically at the time restrictions were lifted and we could sit together in the mosque for exams in early June 2020. In the intermediate period, Adila and the rest of the class, like me, joined the class from our home environments. While the class was offered as part of a mosque educational programme and was conducted before and after lockdown within the realm of the mosque buildings, during the time of online streaming the mosque became somewhat invisible. The sounds, smells and walls of the mosque did not determine the territory or the conduct of the class (Deleuze and Guattari 2012: 362; Bandak 2014: 254). Instead, for a participant like Adila, it became her home environment that constituted the educational territory, and technological infrastructure such as internet connections came to be more significant than the call for salat prayers or noise from a neighbouring classroom. ${ }^{8}$ This did not mean that the mosque where Adila usually would have come for

7 According to Islamic tradition, the Quran was sent from God to the prophet Muhammad as qur'ān, as sounding words. Muslims worldwide learn to recite the Quran following specific rules and regulations that ideally reflect the sounding of the revealed Quran (Groeninck 2016; Gade 2021).

8 The call for salat is called by the Arabic term adhān (Juynboll 2012). Salat (Arabic șalāh) is the Islamic obligatory prayer performed five times daily. On Fridays, the midday prayer (salāt al-žuhr) is performed as a congregational prayer (salät al-jumiah). It is 'incumbent for all free, adult Muslim males' (Katz 2016) to perform this in congregation but not for women (as well as other groups, e.g. travellers). 
the class became irrelevant. When I asked her about the closing of mosque activities, she also noted that she believed that even during lockdown a few people had been going to the mosque to perform salat, since, as she explained, 'a mosque that is empty is not very good. The intention is that it is in use and that salat is performed there' (interview, May 2020). ${ }^{9}$ For Adila, the mosque as a place upholding certain ritual rhythms on behalf of the Muslim community was still important. However, her relation to the mosque changed as infrastructure was digitized and all religious activities resettled in her domestic territory (Deleuze and Guattari 2012: 378, 403). She connected digitally not only to the Quran class and other classes provided by her local mosque, but also to other digital places for Islamic teaching. Her computer and other similar devices all provided the opportunity to make her home a place for Islamic learning during lockdown. Thus, while maintaining religious practices, including educational activities, relied in part on her connection to her local mosque, the change of infrastructure also altered her connection with the mosque and broadened the territory of her quest for Islamic knowledge, as she found an opportunity within the lockdown to search for more and different places of Islamic learning (Larkin 2008b: 66-7). For her as for others I talked to, not being able to be physically present in specific places and come together in specific ways thus stimulated an increase in Islamic studies. In our conversation, Adila described it as follows:

9 It must be stressed that such a practice would not have violated the regulations set by Danish authorities.
Adila: There has been more time for reflections, to read the Quran and search for knowledge via the internet and reading books. So it hasn't necessarily been a bad thing not to be able to go to the mosques because there has been a lot of teaching online by high scholars of Islam. ...

Maria: The mosque has also offered a lot of education [online] but you mean also international scholars?

Adila: Yes, from the United States, England, Australia, Mufti Menk, that guy from Zimbabwe. There are many high scholars who broadcast their messages online.

Many of the women I talked to mentioned that the lockdown situation actually made room for a more contemplative approach to their religion and more thorough studies on their own terms. In June 2021, I talked to Mariam, the woman I visited in the introductory example, about the last year of changing degrees of lockdown. For her, she explained, the situation had meant that she had been able to check out more educational opportunities of different sorts that could be accessed from her home.

The digital mediation of the Islamic educational activities used by the women of this study were vested with a certain immediacy (Larkin 2008b: 49; Meyer 2011). Educational opportunities were described as easily accessible and hence as being close at hand, even if they might also connect with a global world and places as geographically far away from the homes of the women as Australia, as Adila mentioned. As such, the quest for Islamic knowledge also became more decontextualized (Hirschkind 2012: 17), and the lockdown 


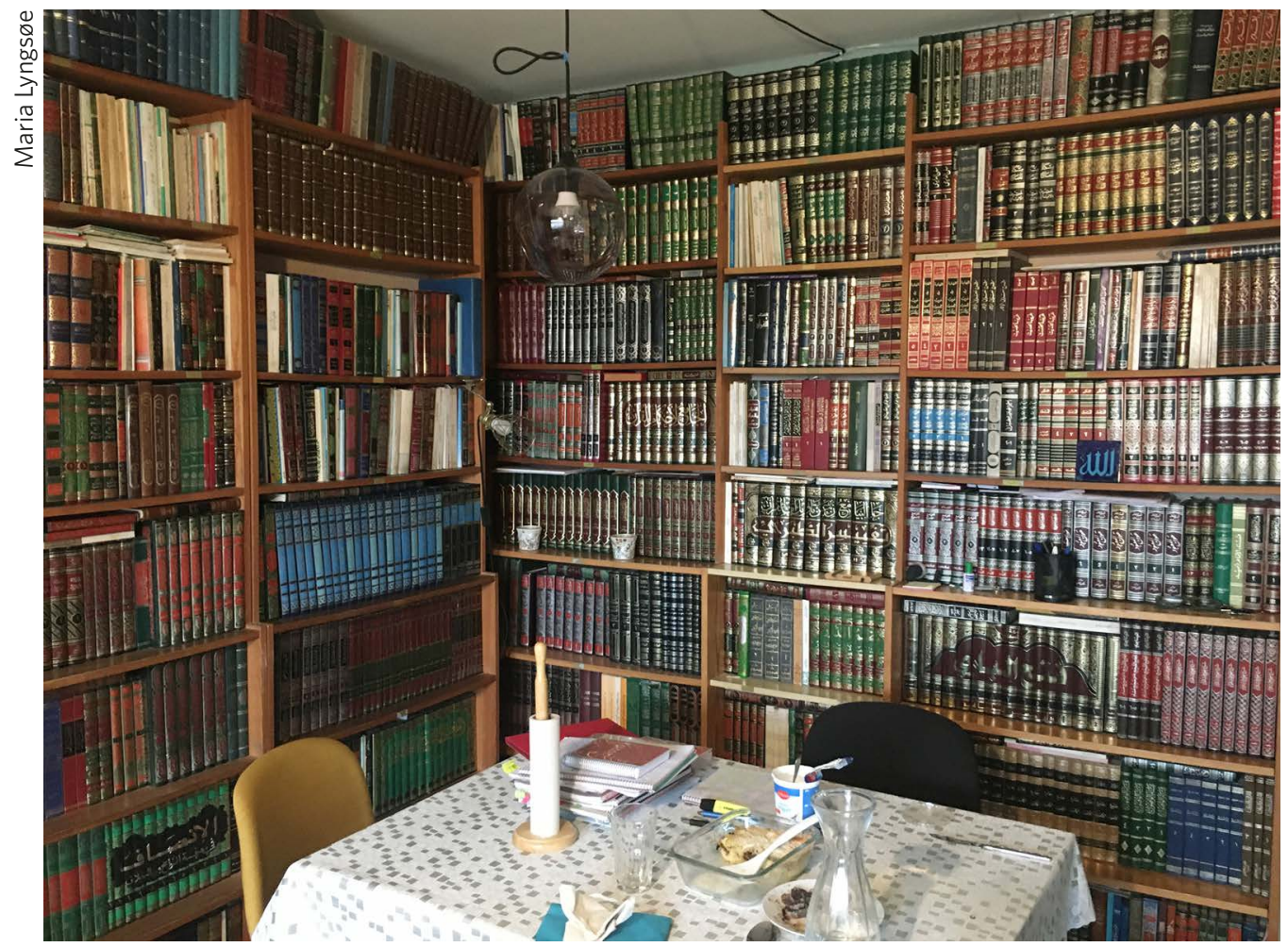

Picture from the living room and study space of one interlocutor. January 2020.

situation furthered a situation where seeking out knowledge became something that was done on more individualized terms. As Hirschkind emphasizes, we should not neglect the fact that online religious practices are also social (p. 18). What the term 'individualized' in this context captures is thus not that meaning or faith are established on individual terms, but that during a situation of lockdown the way the educational opportunities are accessed and structured becomes increasingly individualized owing to the digitizing of infrastructure, being connected to the rhythms of the women's home environments. This also meant that domestic activities could be integrated with the educational activities, as once when a woman from the Quran class started cooking during the session. Local institutions, their sounds, smells and bricks, in contrast became less visible within the Islamic educational territory. At the same time, the women established connections with a broader and more geographically dispersed range of activities.

\section{Islamic education and everyday life}

Many women mentioned that they appreciated that the lockdown situation made it easier to fit their Islamic educational activities into the practicalities of their daily lives. The use of the internet in searching for Islamic knowledge promoted the possibility of interweaving these practices further into rhythms and routines of the everyday. This is the theme of Monica Five Aarset's study (2016) on the use of Quran courses offered from Pakistan and accessed via Skype by Norwegian families. Aarset suggests that we analyse the online streaming of the courses 'in the context of [the] everyday life' of these families (p. 439), as she points to the 
interwovenness of religious practice and choices with other practicalities and priorities in the life of Muslims. Importantly, Aarset thus connects the internationalization represented by the use of Pakistani courses with the families' entanglement in local everyday life. A similar connection appears from the practices of the women in my study. The lockdown situation, so deeply marked by being at home, intensified connections with a broader range of educational activities distributed across the globe, with online connection overstepping or destabilizing the issues of geographical distance. But the lockdown situation simultaneously intensified the integration of the women's Islamic educational practices with everyday life. For example, Amalie, a nurse and mother of two children aged four and six and pregnant with her third child, wrote in her logbook notes that

it is easier as a family with small children to participate in education during these times where everything is online. Otherwise [my husband and I] need to prioritize who can go and who must stay but now we can participate from home. (Interview, May 2020)

From a pragmatic point of efficiency in hectic family life (Aarset 2016: 447), the lockdown and the subsequent digitization of life, including Islamic educational activities, made it easier for Amalie to integrate the rhythms of her Islamic educational activities with those making up her everyday life (Deleuze and Guattari 2012: 391). As the relocation of classes unto Zoom, Facebook and other online media platforms blurred connections to local institutions such as mosques that were now no more immediately accessible than various other opportunities, it also made connections between the Islamic educational practices and family space and life easier to establish.

The involuntary attachment to home and the inability to go to the usual places of education such as local Islamic institutes and mosques that she had hitherto frequented was also what made Mariam join a Danish WhatsApp group for Quranic studies during Ramadan 2020, she explained. However, when I asked Nur, who had initiated this group, if she started the group because of lockdown specifically, she said no. Rather, she explained, she found that it was just in general 'very easy to share knowledge through social media' (interview, May 2020), and added that even if it would have been nice to meet in person, she did not think that people would be able to find the time for it, and therefore the online option would be better in any case. Nur's reply shows that the connections to home and the rhythms of everyday life provoked by lockdown also guided the women's religious practices more generally, and that Islamic educational practices, like other religious endeavours, must be integrated with these rhythms to make sense (Deleuze and Guattari 2012: 369-70, 385 ). The examples show that the digitization of Islamic educational activities offers women the chance to intensify their engagement with Islamic knowledge, something that they welcomed. Even before the lockdown, many women tried to use free time during their everyday lives to enhance their knowledge of Islam and their spiritual engagement; online access to educational activities made this easier, as Amalie and Nur mentioned. However, it should also be noted that reality might not always follow intensions (see also Hirschkind 2006: 89-95). Many women also reflected on the possible discrepancies between their own intensions and actual practices influenced 
by the possibilities that everyday life offers (Schielke 2009). When I picked up the logbook that Mariam had kept, as described in the introduction, she aired her reflections on this. Keeping this logbook, Mariam explained, had made her realize that she actually spends less time on Islamic educational activities than she wants to, and that she was a little 'embarrassed' to realize this (field notes, March 2020). When I talked to her again in June 2021, Mariam also explained that while the online running of classes had made it possible for her to follow more educational opportunities despite a busy schedule, she also found that concentration was hard to maintain when participating online from home after a long day at work. In this way, the integration of the Islamic educational activities that were furthered by digitization both expanded and disturbed Mariam's engagement, as was the case for other women as well.

\section{Missing the feeling of being physically together}

The reterritorialization of Islamic educational activities to the home also represented a time of being away from a community and from people. As Mariam hinted in her reflections (mentioned above), the period of lockdown and coronavirus restrictions also represented a feeling of increased distance from events and social relations. This was a general theme in the women's accounts of their experiences of engaging in Islamic educational activities during the lockdown. These feelings of missing out on physical closeness with fellow students and teachers ran parallel to and preconditioned the process of intensified studies from home with a spatial reorganization of the field and increasing use of non-local sources. Sherin was a woman who participated regularly in a semi- private tafsir class. ${ }^{10}$ This class went online, to be conducted on Zoom, after the lockdown prevented the usual way of gathering, which would be in the private home of the group's teacher. Sherin described the dialectics of her digitized infrastructural setup like this:
From one side, it is nice that you don't need to move from home, you don't need to use the time for transport, so you just sit and have the lessons and it's a blessing, especially in this time of coronavirus. But at the same time, of course, a physical meeting has another flavour and it is also very important. (Interview, May 2020)

This 'flavour' that Sherin misses should be understood metaphorically as referring to the feeling of being together and sharing a social bond. It should also be understood more literally as referring to the physical and sensory experience of meeting in the home of the teacher. Such meetings included the sharing of home-cooked food, drinking tea and coffee and sitting close together in the teacher's living room, perhaps touching the skin or smelling the perfume of one's 'sisters', as the women would commonly call each other. At such meetings, Sherin explained, the women could talk about 'everyday life and maybe problems' (interview, May 2020), and this was not really possible when meeting online. Even if one could pose a question after the class, it was in a more restricted sense, as Zoom would not really accommodate the informal way of relating that Sherin

10 Tafsìr is commonly translated as interpretation'; it refers in this context to the 'branch of Islamic learning concerned with' the meaning of the Quran (Rippin 2012). 

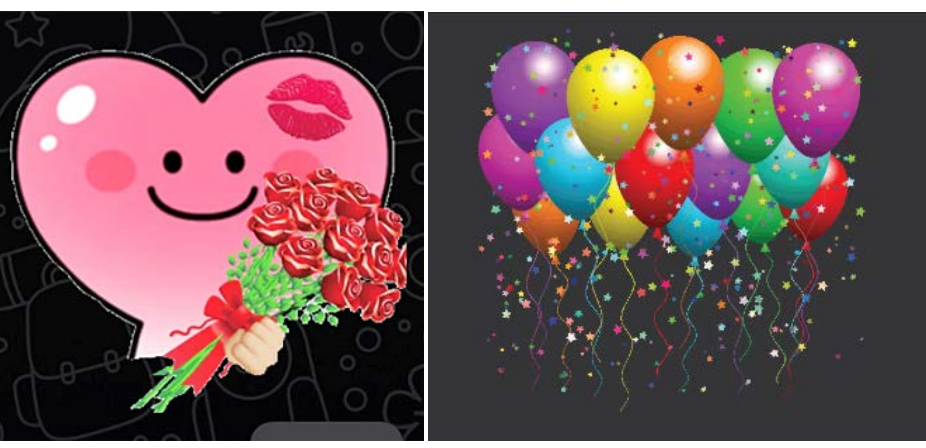

Two examples of the often used supportive emojis posted by women in the WhatsApp group that Sherin shared with her 'sisters'. Posted June 2020.

cherished in the usual physical meetings of the tafsir group.

Hence digital connections also furthered a feeling of distance among classmates. Religion is territorializing, say Deleuze and Guattari (2012: 374). It makes communities and rooms of shared rhythms. In each other's physical presence, it was easier to tune in with one another, to talk and learn about the small things that also matter. Not sharing a physical meeting space made this harder, Sherin explained. In a WhatsApp group that the women in the tafsir shared - the one I was allowed to follow as well - the theme of missing each other when being physically apart was also often raised, and it seemed to be a shared feeling among many participants. The WhatsApp group was also described precisely as a forum for establishing and maintaining closeness to each other in busy everyday life. As digital infrastructure the WhatsApp group was a mode of connecting marked by immediacy, which made it easy to integrate with busy everyday life. As Karen Waltorp sets out in her study of young Muslim women's use of social media to negotiate their identities, the smartphone is (potentially) always at hand, and its mobility means that it can be used on the way and in close connection with everyday surroundings.
As technological infrastructure, WhatsApp communication thus structures relations in a specific way, in that it oversteps time and space. Through WhatsApp, connections to one's sisters are easy to maintain on individual terms of access (Wheeler 2017: 164). Sherin thus also explained that 'with this WhatsApp, we can follow almost every day. Whatever happens to someone, we can inform, we can try to help ... So we have this daily connection. ... It makes things easy' (interview, May 2020). As such, the WhatsApp group made intimate relations easier to maintain and secured the connection between the women in the course of everyday life. But as Sherin and others explained, this connection and the feeling of being part of a community also seemed to rely on getting together and sharing knowledge and experiences in physical meetings, i.e. not online. The women expressed how they especially missed this kind of relating when the forced digitization remodelled the educational space and installed physical distance. This spatial distance was also experienced as an emotional distance.

Samira, the teacher of the class for female converts, who was presented in the introductory example, addressed this issue as well. For Samira, a very important aspect of the class for converts was the establishment of a sense of intimacy and relatedness among the women engaged in this group. This suffered from being physically distanced, Samira explained, when in May 2021 she reflected on a year of primarily online classes. She told me that she is usually really good at sensing how people feel and that it is important to her that all participating women in the class know that she and the other teachers are there to help 
and support everyone. But when you only talk online or in writing via WhatsApp, 'the soft aspect of [teaching] is missing', she explained with regret. Like Sherin, Samira felt out of tune with the class and her community. Mariam had the same experience with a class for women that she used to join each Tuesday in a local Islamic educational institution. While, as described above, she had explored various new Islamic educational opportunities during the time of lockdown, she had also skipped this specific Tuesday class, even though it was possible to join it online. Mariam explained that she likes this class specifically because of the social relations it affords; she enjoys being together with like-minded people and learning through collaboration. When this togetherness was distorted, the class was no longer meaningful for her to participate in. For the women in this study in general, close relations to both teachers and fellow students were often highlighted as crucial for their engagement in Islamic educational activities and for their evaluation of these as meaningful and relevant. Like other authors, Giulia Liberatore (2019) finds a mode of teaching that establishes 'intimate, empathic and less hierarchical relationships between teachers and students' (p. 9) to be specifically influential among female teachers and preachers of Islam (see also Inge 2017; Kloos 2019, 2021). In many of the classes in my study as well, intimate sharing and less hierarchical relations also constituted an important mode of establishing and sharing knowledge. Many women reported that the ability to uphold exactly such relations was impaired when simultaneous psychical togetherness was disrupted. What was missing was what Sherin called 'the flavour' of being physically together. Not so much the institutional frame of the mosque buildings, but the classes as spaces for establishing feelings of community and sharing in physical closeness. From the women's narratives physical closeness and bodily sensations played a crucial role for this establishment. With Deleuze and Guattari, we could say that for the women, being physically together made it easier for them to become 'rhythmic characters' of the same 'melodic landscape' (2012: 373). Making space is an aesthetic, sensorial and embodied practice influenced by the technological infrastructure that saturates space (Larkin 2008b: 167; Deleuze and Guattari 2012: 362-64, 374). While the women could tune in on each other via digital technologies, it was harder for them to establish spaces where they actually felt in tune, 'occupying corresponding frequencies' (Deleuze and Guattari 2012: 385). The way the intensely digitized infrastructure organized space was marked by a dispersal of place and by bodily distance, even when simultaneity characterized connections temporally, as in for example Zoom meetings. This made connections to one's fellow sisters more precarious and more vulnerable to misunderstanding when body language or facial expressions were missing in Whats App messages, or informal conversations could not be shared over a meal after class. Certain modes of connecting were simply not possible to maintain in a field relying solely on digitized infrastructure, and the spatial distance it necessitated also caused experiences of being emotionally distant from fellow students and teachers of Islam. This highlights how the infrastructural changes also affected the very bodies of this study: they influenced and reshaped the sensory aspect of engagement.

\section{Conclusion}

When Danish society was struck by massive restrictions and recommendations on social behaviour to curb the spread of the 
coronavirus in March 2020, digital media became the material objects through which relations and practices in the field of Islamic educational were established and maintained (Larkin 2008b: 250). This article has provided insights into the implications of the coronavirus lockdown for Danish Muslim women's Islamic study practices. Drawing on theoretical points from Deleuze and Guattari (2012) and Larkin (2008b), it has shown how technological infrastructure influences religious practice and the constitution of religious space and communities. For the women engaged in Islamic education, the necessity of using digital media technologies made attendance at activities impossible, reorganized time and space, and changed the conditions for relating to communities. Home became the religious territory, and digitized access to educational activities provided both by local and international sources was one way to secure and maintain religious life during the period of lockdown. This meant that practices became privatized and individualized, as technologies promoted a mode of accessing and studying carried out on more individual terms and in close connection with other daily activities and from within the domestic space. At the same time, the women explained that lockdown had also expanded the horizon of their quest for knowledge. As local and international opportunities were now equally near or distant, they chose more freely between opportunities. This brought about an ambiguous relationship to local mosques and Islamic institutions, which were in one way becoming less important as part of their religious territory, since activities could be maintained without going to these and increasingly without connection to these. On the other hand, the women emphasized the role of local places for upholding Muslim community. Especially, the women expressed a deep-felt lack of being physically together with their fellow Muslim 'sisters'. While technologies made communication immediately accessible, the flavour of being physically together was lost during coronavirus. Hence, it appears that digital infrastructure is endowed with an ambivalence between, on the one hand, an immediate nearness that enables users to integrate participation easily into daily practicalities and makes home a territory of religious activity and community-building, and, on the other, a physical distancing that impairs religious and emotional connections. This ambivalence marked the experiences of my interlocutors during lockdown. A case study such as the present one can show the influence and elucidate the workings of infrastructure on space, bodies and feelings.

Maria Lindebæk Lyngsøe is a Ph.D. fellow in the study of religion at Department of Cross-Cultural and Regional Studies at University of Copenhagen, where she is part of the research project 'Rearticulating Islam: A New Generation

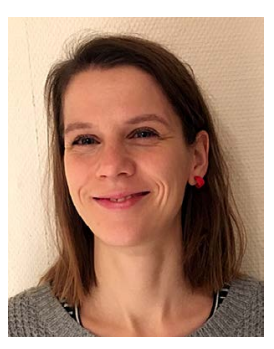
of Muslim Religious Leaders', led by Assistant Professor Simon Stjernholm, funded by VELUX FONDEN (project number 00021825). She specializes in the study of Muslim women's contemporary religious practice, and her current research deals with teaching and learning practices as a way to approach and relate to the divine and form pious subjects.

\section{Acknowledgements}

I am very grateful to the women engaged in Islamic educational activities who took the time to talk to me and invited me to classes and events. I also thank Simon Stjernholm, Åsa Trulsson and Maximilian Lasa for advice and helpful readings of drafts of this article. 


\section{References}

Aarset, Monica F. 2016. 'Transnational practices and local lives. Quran courses via Skype in Norwegian-Pakistani families', Identities 23(4): 438-53, doi: <https://doi.org/10.108 o/1070289X.2015.1024122>.

Ahlin, Tanja, and Fangfang Li. 2019. 'From field sites to field events', Medicine Anthropology Theory 6(2): 1-24, doi: <https://doi. org/10.17157/mat.6.2.655>.

Amit, Vered. 2000. 'Introduction. Constructing the field', in Constructing the Field. Ethnographic Fieldwork in the Contemporary World, ed. Vered Amit (New York: Routledge), 1-18.

Ammerman, Nancy T. 2013. Sacred Stories, Spiritual Tribes. Finding Religion in Everyday Life (Oxford University Press).

Bandak, Andreas. 2014. 'Of refrains and rhythms in contemporary Damascus. Urban space and Christian-Muslim coexistence, Current Anthropology 55(10): 241-68, doi: <https://www.journals.uchicago.edu/ doi/10.1086/678409>.

Cheruvallil-Contractor, Sariya. 2015. 'Online Sufism. Methodological thoughts on researching esoteric Islam in an online context, in Digital Methodologies in the Sociology of Religion, eds. Sariya Cheruvallil-Contractor and Suha Shakkour (Bloomsbury Publishing), 59-70, doi: <http://dx. doi.org/10.5040/9781474256292.ch-006>.

Cowan, Douglas E. 2014. 'The internet', in The Routledge Handbook of Research Methods in the Study of Religion, eds. Michael Stausberg and Steven Engler (London \& New York: Routledge), 459-73.

Deleuze, Gilles, and Félix Guattari. 2012/1987. A Thousand Plateaus. Capitalism and Schizophrenia (London \& New York: Bloomsbury Academic).

Gade, Anna M. 2021. 'Recitation of the Qur'an', in Encyclopedia of the Qur'an, ed. Jane D. McAulliffe (Leiden: Brill), doi: $\quad<\mathrm{http}$ ://dx.doi.org.ep.fjernadgang.kb.dk/10.1163/1875-3922_q3_ EQCOM_00168>.

Gardet, L. 2012. 'Du'ä', in Encyclopaedia of Islam, Second Edition, eds. P. Bearman et al. (Leiden: Brill), doi: <http://dx.doi.org. ep.fjernadgang.kb.dk/10.1163/1573-3912_ islam_COM_0195>.
Gori, Alessandro. 2021. 'Home prayer, unattended funerals and social responsibility. Muslims in Italy and the coronavirus outbreak (March-May 2020)', Tidsskrift for Islamforskning 14(2): 63-80, doi: <https:// doi.org/10.7146/tifo.v15i2.125915>.

Groeninck, Mieke. 2016. 'The relationship between words and being in the world for students of Quranic recitation in Brussels, Contemporary Islam 10(2): 249-66, doi: <https://doi.org/10.1007/ s11562-016-0357-3>.

Harvey, Graham. 2014. 'Field research: participant observation', in The Routledge Handbook of Research Methods in the Study of Religion, eds. Michael Stausberg and Steven Engler (New York: Routledge), 217-44.

Hirschkind, Charles. 2006. The Ethical Soundscape. Cassette Sermons and Islamic Counterpolitics (New York: Colombia University Press).

Hirschkind, Charles. 2008. 'Cultures of death. Media, religion, bioethics', Social Text 26(3): 39-58, doi: <https://doi. org/10.1215/01642472-2008-003>.

Hirschkind, Charles. 2012. 'Experiments in devotion online. The YouTube Khutba', International Journal of Middle East Studies 44: 5-21, doi: <https://doi.org/10.1017/ So02074381100122X>.

Hirschkind, Charles, and Brian Larkin. 2008. 'Introduction. Media and the political forms of religion', Social Text 26(3): 1-9, doi: <https://doi. org/10.1215/01642472-2000-001>.

Inge, Anabel. 2017. The Making of a Salafi Woman. Paths to Conversion (New York: Oxford University Press).

Juynboll, Th. W. 2012. 'Adhān', in Encyclopaedia of Islam, Second Edition, eds. P. Bearman et al. (Leiden: Brill), doi: <http://dx.doi.org. ep.fjernadgang.kb.dk/10.1163/1573-3912_ islam_SIM_0302>.

Katz, Marion H. 2016. 'Friday prayer', in Encyclopeadia of Islam, Three, eds. Kate Fleet et al. (Leiden: Brill), doi: <http://dx.doi.org.ep. fjernadgang.kb.dk/10.1163/1573-3912_ ei3_COM_27193>.

Kloos, David. 2019. 'Experts beyond discourse. Women, Islamic authority, and the performance of professionalism in Malaysia, American Ethnologist 46(2): 162-75, doi: $<$ https://doi.org/10.1111/amet.12762>. 
Kloos, David. 2021. 'Risky appearances, skillful performances. Female Islamic preachers and professional style in Malaysia, American Anthropologist 123(2): 278-91, doi: $<$ https://doi.org/10.1111/aman.13556>.

Kühle, Lene. 2021. 'Danish Muslims during COVID-19. Religion and pandemics in a postsecular society', Tidsskrift for Islamforskning 14(2): 13-39, doi: <https://doi. org/10.7146/tifo.v15i2.125912>.

Kühle, Lene, and Tina L. Larsen. 2021. " "Forced” online religion. Religious minority and majority communities' media usage during the COVID-19 lockdown', Religions 12(7), doi: <https://doi.org/10.3390/ rel12070496>.

Larkin, Brian. 1998. 'Media technologies and the design for modern living: a symposium, Visual Anthropology Review 14(2): 11-13.

Larkin, Brian. 2008a. 'Ahmed Deedat and the form of Islamic Evangelism', Social Text 26(3): 101-21, doi: <https://doi. org/10.1215/01642472-2008-006>.

Larkin, Brian. 2008b. Signal and Noise. Media, Infrastructure, and Urban Culture in Nigeria (Durham, NC: Duke University Press).

Larsen, Tina L. et al. 2021. "Vi har lukket ned for alle aktiviteter". Håndteringen af COVID-19-krisen hos anerkendte trossamfund i Danmark, forår 2020', Religion i Danmark 2020 10(1): 78-91.

Liberatore, Giulia. 2019. 'Guidance as “women's work": a new generation of female Islamic authorities in Britain, Religions 10(11): 1-16, doi: <https://doi.org/10.339o/ rel10110601>.

Makboul, Laila. 2020. 'Going online. Saudi female intellectual preacher in the new media, in Muslim Preaching in the Middle East and Beyond. Historical and Contemporary Case Studies, eds. Simon Stjernholm and Elisabeth Özdalga (Edinburgh University Press), 107-31.

Markham, Annette. 2016. 'Ethnography in the digital internet era. From field to flows, descriptions, interventions', in The Sage Handbook of Qualiative Research, eds. Norman K. Denzin and Yvonna S. Lincoln (Thousand Oaks, CA: SAGE Publications), 650-68.

Markham, Annette. 2020. 'Ways of being in the digital age', in Metaphors of the Internet. Ways of Being in the Age of Ubiquity, eds.
Annette N. Markham and Katrin Tiidenberg (New York: Peter Lang Publishing), 3-11.

Massumi, Brian. 2012. 'Translator's foreword. Pleasure of philosophy', in A Thousand Plateaus. Capitalism and Schizophrenia, Gilles Deleuze and Félix Guattari (London \& New York: Bloomsbury Academic), vii-xiv.

Meyer, Birgit. 2011. 'Mediation and immediacy: sensational forms, semiotic ideologies and the question of the medium', Social Anthropology 19(1): 23-39, doi: <https://doi.org/1 0.1111/j.1469-8676.2010.00137.x>.

Meyer, Birgit. 2020. 'Religion as mediation, Entangled Religions 11(3): 10731, doi: <https://doi.org/10.13154/ er.11.2020.8444>.

Mittermaier, Amira. 2011. Dreams that Matter. Egyptian Landscapes of the Imagination (Berkeley, Los Angeles, and London: University of California Press).

Moll, Yasmin. 2018. 'Television is not radio. Theologies of mediation in the Egyptian Islamic revival', Cultural Anthropology 33(2): 233-65, doi: <https://doi.org/10.14506/ ca33.2.07>

Moll, Yasmin. 2020. 'The idea of Islamic media. The Qur'an and the decolonization of mass communication', International Journal of Middle East Studies 52(4): 623-42, doi: <https://doi.org/10.1017/ Soo $20743820000781>$.

Rippin, A. 2012. 'Tafsīr', in Encyclopaedia of Islam, Second Edition, eds. P. Bearman et al. (Leiden: Brill), doi: <http://dx.doi.org. ep.fjernadgang.kb.dk/10.1163/1573-3912_ islam_SIM_7294>.

Schielke, Samuli. 2009. 'Being good in Ramadan. Ambivalence, fragmentation, and the moral self in the lives of young Egyptians', The Journal of the Royal Anthropological Institute 15: 24-40, doi: <https.doi. org/10.1002/9781444324402.ch2>.

Schulz, Dorothea. 2012a. 'Dis/embodying authority: female radio preachers and the ambivalences of mass-mediated speech in Mali, International Journal of Middle East Studies 44(1): 23-43, doi: <https://doi. org/10.1017/Soo20743811001231>.

Schulz, Dorothea. 2012b. Muslims and New Media in West Africa. Pathways to God (Bloomington \& Indianapolis: Indiana University Press). 
Schulz, Dorothea. 2015. 'Mediating authority. Media technologies and the generation of charismatic appeal in southern Mali, Culture and Religion 16(2): 125-45, doi: $<$ https://doi.org/10.1080/14755610.2015.1 058525>.

Sorgenfrei, Simon. 2021. " "Perhaps we see it in negative terms, but, ultimately, it is positive". The responses of Swedish Salafis to COVID-19,' Tidsskrift for Islamforskning 14(2): 40-62, doi: <https://doi.org/10.7146/ tifo.v15i2.125959>.

Sterne, Jonathan. 2008. 'Enemy voice', Social Text 26(3): 79-100, doi: <https://doi. org/10.1215/01642472-2008-005>.

Stjernholm, Simon. 2019. 'DIY preaching and Muslim religious authority', Journal of Muslims in Europe 8(2): 197-215, doi: $<10.1163 / 22117954-12341393>$.

Stjernholm, Simon. 2020. 'Brief reminders. Muslim preacher, mediation, and time', in Muslim Preaching in the Middle East and Beyond. Historical and Contemporary Case Studies, eds. Simon Stjernholm and Elisabeth Özdalga (Edinburgh University Press), 132-51.

Stjernholm, Simon, and Elisabeth Özdalga. 2020. 'Introduction', in Muslim Preaching in the Middle East and Beyond. Historical and Contemporary Case Studies, eds. Simon Stjernholm and Elisabeth Özdalga (Edinburgh University Press), 1-16.

Waltorp, Karen. 2015. 'Keeping cool, staying virtuous. Social media and the composite habitus', MedieKultur 58: 49-67, doi: <https://doi.org/10.7146/mediekultur. v31i58.19373>.

Wheeler, Kayla R. 2017. 'The ethics of conducting virtual ethnography on visual platforms', Fieldwork in Religion 2(12): 163-78. 